\author{
Aleksander Ostapiuk \\ Wroclaw University of Economics and Business \\ Faculty of Economic Sciences \\ Department of Ecological Economics \\ e-mail: aleksander.ostapiuk@gmail.com
}

\title{
Value-free paradise is lost. Economists could learn from artists
}

\begin{abstract}
Despite the conclusions from the contemporary philosophy of science, many economists cherish the ideal of positive science. Therefore, value-free economics is still the central paradigm in economics. The first aim of the paper is to investigate economics' axiomatic assumptions from an epistemological perspective. The critical analysis of the literature shows that the positive-normative dichotomy is exaggerated. Moreover, value-free economics is based on normative foundations that have a negative impact on individuals and society. The paper's second aim is to show that economics' normativity is not a problem because the discussion concerning values is possible and unavoidable. In this context, Weber and other methodologists are investigated. The conclusion of the paper is that science can thrive without strict methodological rules thanks to institutional mechanisms. Therefore, economists could learn from artists who accept the world without absolute rules. This perspective opens the possibility for methodological pluralism and normative approaches.
\end{abstract}

Keywords: philosophy of science, methodology of economics, value-free economics, Max Weber

JEL Classification: B20, B40, B41 


\section{Introduction}

Although the philosophy of science dismissed logical positivism in the $1960 \mathrm{~s}$, many economists cherish some version of this position to this day. Despite the criticism, value-free economics can be perceived as the central paradigm in economics. The paper revisits conclusions from the philosophy of science to synthesize criticism of value-free economics. Thanks to broad philosophical analysis, the limits of economists' belief in positive science can be highlighted.

The article starts with a short introduction of the key insights from the contemporary philosophy of science. The conclusion is that the search for truth and objectivity is not achievable. Value-free economics is analyzed from the epistemological perspective to indicate its origins. The goal is to present why economists are not necessarily more scientific than other social scientists and why the belief in being positive science is not justified. This historical analysis is vital because neoclassical economics was thought to be more scientific due to its reliance on mathematics and the deductive method. With time, some economists started to believe in the axiomatic assumptions of their theories. It results from a specific understanding of the utility and rationality used in the economic approach (Becker, 1976). The article analyzes if the belief in positive economics negatively impacts individuals and society.

Despite the problems, many economists stick to logical positivism because they think that the only alternative is "anything goes" (Feyerabend, 1993). It is argued that economists exaggerate the danger of relativity. Firstly, they misinterpreted McCloskey's rhetorical approach. Secondly, they misinterpreted Weber, who is treated as the father of value-free economics.

The paper's overarching goal is to persuade the reader that economists should not aspire to be like mathematicians but to learn from artists when it comes to methodology. For them, relativity is not a problem. Although the rules are not clearly defined, it is possible to distinguish between excellent and terrible works of art. Of course, science relies on data and logic, which differentiates it from art. Therefore, economists should only emulate some features of artists, not try to be artists through and through. From the article's perspective, accepting the relativity of science means openness toward methodological pluralism and normative approaches, which some economists dismiss as unscientific.

Although there have been significant changes in mainstream economics in recent years (Colander, 2000; Colander, Holt \& Rosser, 2004; Davis, 2006; Cedrini \& Fontana, 2018), many economists still cherish the value-free paradigm (Berg \& Gigerenzer, 2010; Dow, 2012; Lawson, 2015; Madra, 2016). Despite the historical context, this article can contribute to contemporary debates concerning economics' status by presenting the arguments for pluralism and the incorporation of some values into economics. 


\section{The philosophy of science}

Before going toward economics, we need to start our discussion from the philosophy of science. The purpose is to show that the goal of enlightenment (finding universal laws, the ultimate truth) has not been achieved, and it will not be achieved in the future. Although this statement is well-known in philosophy, some economists still believe in positivism. Moreover, many economists agree with the statement that "economics is what economists do," and they dismiss any methodological discussion about their field. This situation is not exclusive to economists. Other scientists also treat the philosophy of science as unnecessary. This attitude is attributed to Feynman, who wrote that the "philosophy of science is about as useful to scientists as ornithology is to birds." The analysis of the contemporary philosophy of science shows that economist's belief in logical positivism is unjustified, and the rules of the scientific game have changed. Therefore, economists should not rely on positivistic methodology unhesitatingly.

Until the 1950 and 1960s, logical positivism was very popular among all scientists, not only economists. However, from the 1970s, it started to be not only obsolete but something that philosophers sneered at. As a result, the term "positivism" is now exclusively a "philosophical Booadjective" (Hutchison, 1981, p. 204).

Popper (1959) was one of the philosophers to make logical positivism obsolete. He was a critic of logical positivism because he believed that science is based on deduction, not induction. First comes the hypothesis, and later we check it empirically. Popper gave the example of his students to show why theory came before observation. During the lecture, he asked them to observe and write down their observations. The students immediately asked, "Observe. But what?" Popper indicated that our observations are theory-laden, to underline that it is essential for scientists to have a critical attitude toward their theories. People tend to look for patterns, and it is easy to confirm any theory. The evidence is everywhere. Even though Popper thought that we can find proof for our theories, it does not mean that our theories are right. Scientists need to embrace the idea of fallibilism and keep in mind that they can be wrong. The problem of confirmation is not only a psychological tendency. The very method of confirmation is not valid. This problem is called "the raven paradox," where any nonblack object (e.g., a shoe) confirms that all ravens are black (Hempel, 1945).

Popper proposes falsificationism to resolve this problem. For him, a theory is scientific, not when we can confirm it but when we can find empirical proof that dismisses our theory. In the case of the hypothesis "all ravens are black," we should look for white ravens that can falsify our theory. Falsificationism has two purposes. Firstly, demarcation (distinguishing science from non-science). Secondly, methodological (how science should be practiced). For Popper, Einstein's theory of relativity is the best example of scientific theory. Einstein proposed a bold hypothesis that could be easily falsified because of the risky prediction (very specific). It is contrary to Marxism or Freudism, where it is possible to explain two opposite pieces of evidence with the same theory. Most importantly for Popper, even if a theory is not 
falsified, it does not mean that it is true. Accepting some theory is always provisional and can be falsified in the future by a new experiment.

Falsification is right in spirit, but it has problems. Because every theory can prove to be wrong in the future, none of them is absolutely true. If a theory successfully passes falsification, the only thing that can be said is that it is closer to the truth. Popper proposed the concept of verisimilitude to indicate which theory is closer to the truth (one that was falsified 1000 times or one that was falsified only one time). However, this method had never worked, and comparisons could not be made (see Miller, 1974).

Quine is the next philosopher in the story. Quine (1951) rejected the analytic/synthetic dichotomy used by logical positivists. Due to the web of beliefs, there is no epistemological way to make a clear distinction between logical and empirical dimensions. Quine's argumentation involves language, which is too large a topic to be covered in this article. Therefore, only the theory of underdetermination is analyzed. In a nutshell, it means that even if we refute some scientific theory through empirical evidence, these tests are not definitive because no theory is ever tested in isolation. To conduct an empirical test, many auxiliary hypotheses must be assumed. For example, the testing technique, the boundary conditions, the role of ceteris paribus, and many others (Hands, 2001, p. 108). Let us return to the raven example. Before we perform the test, we need to know what kind of bird a raven is because a white bird similar to a raven can exist or "in the process of spray-painting the local bridge the painters accidentally sprayed a raven nest, as to suggest that there really are nonblack ravens" (p. 108). When contradictory evidence is discovered, there is no way to know whether an auxiliary hypothesis or theory itself is wrong because of underdetermination. The discovery of the planet Neptune is an example of this problem. When it was found that Uranus's motion did not match the predictions of Newton's law, it was not Newton's laws that the scientists rejected but the theory about there being seven planets in the solar system. They found an eighth planet (Pluto). In the end, scientists need to choose one option without a conclusive argument.

If we do not have any rational rules to compare different theories, how should we decide which is better? Kuhn has the answer to this question, but his answer undermines the rational view of science. Kuhn underlines that every theory is theory-laden, and he introduces the concept of "paradigm," which can be described as the lens by which scientists look at reality. He argues that scientists cannot rationally decide which theory is better, and they choose as a community between different paradigms. For example, in the $16^{\text {th }}$ century, scientists supported the Copernican system, and the Ptolemaic system started to become obsolete even though, at that time, the evidence did not support the Copernican theory. Kuhn, as a historian of science, observed that scientists do not treat anomalies as counterexamples of their theories. In the $19^{\text {th }}$ century, scientists did not dismiss Newton's laws because the predictions did not match. Instead, they changed the auxiliary hypothesis, and they searched for a new planet. This example shows that scientists do not always follow falsificationism. Therefore, a "paradigm" demonstrates that we trust in some theory, and we look at reality through the lenses that some theory 
provides. Kuhn argues that different paradigms are incommensurable with each other. We cannot compare them because they use entirely different languages to describe reality. So-called facts will not help us with a decision because how facts are interpreted depends on the paradigm that we believe. What is essential for Kuhn is that a paradigm concerns not only one person but the whole scientific community. Therefore, he underlines the context of discovery (science is embedded in society).

Kuhn argues against the enlightenment view of science, where knowledge cumulates with time. Kuhn (1996) argues that science develops from revolution to revolution, which he calls "paradigm shifts." Before a revolution, in the time of "normal science," scientists follow a paradigm, and they are dogmatic. They try to dismiss anomalies and find a way to defend their paradigm. However, with time, the paradigm has to deal with more and more anomalies. When a paradigm cannot deal with the anomalies and cannot resolve the accumulating problems, science falls into crisis. Dogmatic scientists start to be open to a change and philosophical reflection of their work. Scientists want to know some new rules that would make their work successful again. This mechanism occurred in the 1980s, when economists started to be interested in philosophy and the philosophy of economics came to life.

A scientific revolution is similar to a social revolution because there are no rational arguments to decide which theory is better. In the end, the scientific community decides which paradigm is better. This process often takes the form of a struggle between older scientists, who try to defend their theory, and young scientists, who criticize the old order. In the end, the group that wins has more power, more persuasion, and more supporters. In economics, this struggle arose in the 1980s, when behavioral economics criticized the neoclassical paradigm. Initially, the conclusions from behavioral economics were in many ways dismissed (Thaler, 2015). However, in recent years, behavioral economics started to be identified with the mainstream (Thaler, 2016; Angner, 2019). Kuhn changed the game for philosophers of science. They had to agree to the relativity of scientific methods.

The last philosopher in the story is Feyerabend, who introduced epistemological anarchism, which is captured by the phrase "anything goes". Scientists sometimes misinterpret his work, perceiving him as a lunatic. However, he did not criticize science for the sake of criticism. He displayed some of the problems of science because he wanted it to do better. Firstly, he argued against authoritative and dogmatic science, which behaves like a church. Feyerabend cautioned against people who think that they know what the truth is. In this sense, he was a fierce critic of the fundamentalist idea of truth. For him, science started to behave like a church because it believes in its own infallibility, and it tries to make scientific methods the only proven tool for understanding the world.

Secondly, he argues that science should not have any methodological rules because none of them guarantee success. He challenged scientists to present some scientific methodology, and he would prove that it did not work at some point in history. Feyerabend (1993) enjoyed giving examples of theories that were discovered because scientists did not follow the ruling methodology at that time. He 
showed that a particular methodology can be effective in one case and ineffective in another. It means that scientists just do not know which rules work and which do not. Therefore, we all should be anarchists in methodology and criticize our theories. This attitude can lead to discoveries in science.

Of course, the philosophy of science did not end with Feyerabend and the 1980s. Since then, many different approaches in the framework of constructivism have developed (e.g., feminist epistemology, the sociology of science, postmodernism). All of these approaches are important, but the discussion must end here due to the limits of the article. The essential fact is that they use conclusions from Kuhn, Quine, and Feyerabend. All of them criticize the fundamentalistic epistemology of science. They underline the problems of theory-ladenness, underdetermination, socially constructed knowledge, objectivity, and scientific facts.

The purpose of this introduction was to present that the fundamentalist idea of epistemology and truth is dead. There are no firm rules by which sciences can be cultivated. However, many economists do not care about this state of affairs, and they do science as if nothing has happened. To this day, many economists are positivistic in spirit, and they believe in facts, falsificationism, independence between theory and reality, and is/ought distinction.

\section{Value-free economics}

Before starting our analysis of value-free economics, some arguments have to be made to justify the claim that positivism is still a position held by some economists. A few words are necessary because many argue that economics has transformed in the last years due to the incorporation of knowledge from other social sciences like psychology (behavioral economics) and sociology (new institutional economics). Therefore, contemporary mainstream economics is different from orthodox neoclassical economics from the 1950s (e.g., Colander, 2000; Colander et al., 2004; Davis, 2006; Cedrini \& Fontana, 2018). The paragon of the transformation of economics is behavioral economics, which started to be perceived as the new mainstream (Thaler, 2016; Angner, 2019). Moreover, it is argued that economics is not so theoretical anymore, and there has been an "empirical turn" in recent years (Backhouse \& Cherrier, 2017). In general, the process of opening economics to other social sciences has been noticed. It is called "reverse imperialism," which also indicates that economics is pluralistic in methodology, and it does not rely only on positivism.

However, many argue that despite the changes, the foundations of economics have not changed, and mainstream economics works as it used to (Berg \& Gigerenzer, 2010; Dow, 2012; Lawson, 2015; Madra, 2016; Ostapiuk, 2019a, 2020). Everyone agrees that economics has incorporated many insights from other social sciences. However, they are perceived only as adjustments, whereas the paradigm has not changed. Many economists still rely on positivism and believe in objective and valuefree economics based on deduction and axiomatic revealed preference theory (viz. 
rationality, utility, and homo economicus). To see that mainstream economics has not changed significantly, we can look at syllabuses and textbooks (Ratajczak, 2014; Graupe, 2019). The dominance of mainstream economics is also visible when analyzing which journals are the most influential and who holds power in academia (Fourcade, Ollion \& Algan, 2015; Akerlof, 2020).

Therefore, McCloskey's forty-year-old description of the methodology of economics is, in many ways, still accurate and worth analyzing.

(1) Prediction (and control) is the goal of science.

(2) Only the observable implications (or predictions) of a theory matter to its truth.

(3) Observability entails objective, reproducible experiments.

(4) If (and only if) an experimental implication of a theory proves false is the theory proved false.

(5) Objectivity is to be treasured; subjective "observation" (introspection) is not scientific knowledge.

(6) Kelvin's Dictum: "When you cannot express it in numbers, your knowledge is of a meagre and unsatisfactory kind."

(7) Introspection, metaphysical belief, aesthetics, and the like may well figure in the discovery of an hypothesis but cannot figure in its justification.

(8) It is the business of methodology to demarcate scientific reasoning from non-scientific, positive from normative.

(9) A scientific explanation of an event brings the event under a covering law.

(10) Scientists, for instance economic scientists, have nothing to say as scientists about values, whether of morality or art.

(11) Hume's Fork (McCloskey, 1983, pp. 484-485)

In this section, most of these points are analyzed. The goal is to show how economics can hold a positivistic view of science despite its obsoleteness. In this article, neoclassical economics is perceived as value-free economics because both are based mainly on revealed preference theory, which is not interested in human goals, assumes that people do what is best for them, and rationality is defined by technical criteria. The mathematization of economics after World War II is one of the reasons why economists still believe in positivism. Economists want to be like hard science (physic envy). Therefore, they search for universal rules and models that are consciously unrealistic. Much ink has been spilled about these issues (Weintraub, 2002; Mirowski, 2002; Ostapiuk, 2017). Therefore, here only one thing about mathematization is underlined. Many economists follow Samuelson, who wrote that "Mathematics is language" (1952, p. 56). It is important to understand that economists did not invent this idea. They took if from logical positivism, which perceives mathematics as a metalanguage for all science (Mirowski, 2002).

Logical positivism definitely influenced Robbins (1932), and Witztum indicates three central tenets of Robbins' most important essay:

(1) The subject matter of economics is the tension between scarcity and wants (the means-ends problem). 
(2) Economics is based on axioms (abstractions) which are derived from experi-ence and which lead to statements about reality (hence, the 'scientific' nature of the subject).

(3) Economics is not concerned with ends but only with the means available to achieve those ends. It is thus, value-free. (Witztum, 2007, p. 58)

These tenets were necessary to achieve three goals: (1) Define economic science as the study of scarcity-constrained rational choice, (2) Put economics on a firmer epistemological foundation (moving away from hedonism), (3) Make an argument against interpersonal utility comparisons (Hands, 2007). The most critical issue from this article's perspective is the third one-value-freeness, which creates an abyss between normative and positive approaches.

Before analyzing Robbin's view, it is essential to present how logical positivism classifies sentences to comprehend the distinction between normative and positive approaches that prevails in economics. Logical positivists introduced a tripartite classification of sentences: (1) Synthetic, (2) Analytic, (3) Nonsense (Putnam, 2002, p. 10). Synthetic judgments are empirically verifiable or falsifiable. They contain statements that can be verified by reality (facts). For example, we can say that Mount Everest is the highest mountain in the world. It is easy to check whether this statement is true or false. The second type of statement is one that cannot be verified by reality. These analytical statements take the form of tautologies. This means that we can indicate whether they are true or false based on the logical rules alone. The purpose of tautologies is not to tell something about reality but to show the world's logical structure. For example, we assume that the sum of angles in a triangle is $180^{\circ}$. The third group of statements includes ethical, metaphysical, and aesthetic judgments. Logical positivists perceive them as unscientific because they are unverifiable. For example, from the statement "killing is wrong," we cannot derive any statements which will tell us about future experiences. Therefore, this statement is unverifiable and nonsensical.

Before logical positivism, there was a distinction between normative and positive approaches in economics. Keynes made the distinction. The separation of positive and normative was the part of Keynes's more general distinction between positive science, normative science, and art. Positive science contains a study of fact (what is), normative science contains the study of norms and rules (what ought to be), and art is focused on policy application (what can be achieved) (Keynes, 1999, p. 22). In the beginning, there was a clear difference between the positive and normative approaches, but economists did not undermine the necessity of the normative approach. They thought that ethics is necessary, but it should not be an area of interest for economics. One of the reasons for this was specialization. Economists could not deal with every problem, so they had to specialize. Until the 1920s, most economists believed that the relationship between economics and ethics was hierarchical. Economics was the science of wealth [Jevons, Mill, Smith], and ethics used insights from economics to assess which actions were ethically desirable. In a value-free approach, economists are like engineers who tell us how to resolve some problems efficiently, but they will not say what we should do. They only help people achieve the goals that they set themselves. 
Economists are proud of this separation from ethics because they can be perceived as objective scientists who deal only with facts.

Specialization was an important factor in dismissing ethics from economics, but it was Robbins who established the strict dichotomy between normative and positive economics. He underlined the difference between ethics and economics:

Economics deals with ascertainable facts; ethics with valuations and obligations. The two fields of inquiry are not on the same plane of discourse. Between the generalisations of positive and normative studies there is a logical gulf fixed which no ingenuity can disguise and no juxtaposition in space or time bridge over. (Robbins, 1932, p. 132)

As a result of logical positivism, all value judgments were put into the one bag of nonsenses that we cannot rationally discuss. Due to these problems, Robbins (1932, p. 91) wanted to distinguish economics from ethics, arguing that "economic analysis is wertfrei (value-free)". Later, economics became, in the words of Sen, "self-consciously non-ethical" (1987, p. 2).

\subsection{The positive vs. normative approach}

In economics, the dichotomy between positive and normative, facts and values, looks straightforward. However, it has long been the subject of philosophical debate. Much of the discussion can be traced to Hume. This is why the is/ought distinction is called "Hume's dichotomy," "Hume's fork," and "Hume's guillotine". Hume's primary concern was to block efforts to ground ethics in the facts of nature (Putnam, 2002, p. 2).

Hume was right that there is no relationship between the statements "I give to charity" and "I ought to give to charity." That something is does not imply that it should be that way, and that because it should be that way does not imply that it is. Hence, the difference between "is" and "ought" seems significant enough to call it a dichotomy (Hands, 2012). However, the fact/value dichotomy became something different than in Hume's writing. He did not use a term which we now call "value judgments." Admittedly he discusses individual value terms, for example, "virtue," "ought," and so on. However, he puts them into the context of ethics (Putnam, 2002, pp. 18-19). Thus, he writes about ethical judgments, not about all value judgments.

Later, many philosophers forgot about this distinction, and ethical statements started to be identified with value statements. This is visible in the case of positivists. Carnap generally speaks not of "value judgments" but only of the statements of "regulative ethics". The goal of positivists was to challenge the objectivity and rationality of ethics. So, their fact/value dichotomy was not based on any serious examination of the nature of values. They examined the nature of "fact" in a narrow empiricist spirit (Putnam, 2002, pp. 28-29). Therefore, the proper analysis is necessary if we want to understand the nature of value judgments. Hands indicates that normative statements are something more than ethical valuations: 
In general normative terms are simply terms that are action-guiding or prescriptive, and normative statements are statements involving such terms. The relevant norms might be social, legal, epistemological, aesthetic, or a host of other types; ethical norms are just one very special case of such prescriptive terms. (Hands, 2012, p. 9)

Outside economics, it goes without saying that not everything that is "normative" involves ethics. For example, if someone says, "you ought to eat more fruit," it does not mean that you should eat it to be more moral. It means that you ought to eat fruit to be healthy. Therefore, it is a norm but the norm of good health, not an ethical norm. Economists have problems with this distinction, which is visible in welfare economics, where any value component is automatically considered ethical. The problem is even deeper. Mongin writes:

The economists' confounding of ethical with non-ethical evaluations is perhaps only secondary; they are trapped into confusion at an earlier stage. They think of evaluations in terms of judgments, not propositions. This psychologistic preconception fosters the belief that there cannot be an evaluation without a person's commitment, and personal commitments are supposedly typical of morality. (2001, p. 13)

So, if I say, "I do believe that the recent actions of the government were positive," it does not always mean that I want to evaluate their actions. It could also mean that I give information to someone about some actions of the government. Terms like "honest," "good," or "courageous" are thick predicates of morality that have both an evaluative and a descriptive side, in contrast to ethical good-typically thin predicate (Mongin, 2001).

\subsection{The influence of utilitarianism}

Economists sometimes unknowingly derive ought from is. It is possible because economics is influenced by utilitarianism, which is a consequentialist system. For a utilitarian, one ought to do what gives the most pleasure. Therefore, if A causes more pleasure than B, then A ought to be done. In this way, utilitarianism connects economic evaluations with prescriptions (Mongin, 2001). These assumptions lead economists to choose a particular policy. If an economist had to choose between policy A and B, she would probably use this criterion: "The best (good) policy (ceteris paribus) is the one that makes people better off (that is, it leads to the highest level of utility or preference satisfaction among the relevant individuals)" (Hands, 2012, p. 16). Therefore, if economic analysis tells us that policy A (ceteris paribus) makes people better off than policy B, then society ought to do A. Of course, economists do not say what things make people better off. However, they assume that what individuals do maximizes their utility. Utility in economics is entirely different from Bentham's utility and the utility used by marginalists. Sometimes economists speak about individuals who are aiming to maximize utility. However, it does not mean that utility is perceived as an ultimately good thing. 
Utility maximizers only do what they prefer. To say that agents maximize their utility says nothing about the nature of their preferences. It only connects preference and choice. Rational individuals rank available alternatives and choose what they prefer the most (Hausman, 1992, p. 18). In the end, economics knowing what is (what people do-positive facts) tells us how it ought to be (normative).

The next problem also arises from the is/ought dichotomy. For economists, this distinction proves that economics is positive and value-free. Klappholz (1964, pp. 98-99) writes:

The 'orthodox' position rests on Hume's observation that norms or proposals cannot be deduced from descriptive statements alone... Since the scientific part of economics consists exclusively of descriptive statements, it cannot have any ethical entailment, and is therefore value-free. If this is what we mean by 'valuefree' then... it seems trivially true that economics, and the social sciences in general, can be value-free.

It means that "positive economics starts from assumptions that are phrased in terms of factual statements alone and it proceeds by making deductions from these statements" (Mongin, 2001, p. 20). However, this understanding is flawed because Hume's dichotomy only works when initial premises are exclusively factual, and economics contains the evaluative vocabulary of preference. The statements like "I prefer A to B" designate an evaluative concept, which makes the proposition an evaluative one (2001). Because this is not well known among economists, many still perceive the Pareto optimum and effectiveness as value-free concepts. The Pareto optimum is normatively laden. Therefore, welfare economics cannot be perceived as positive science (Blaug, 1992; Hausman \& McPherson, 2006). The Pareto criterion is not value-free because it is based entirely on satisfying the preferences of a particular economic agent. Therefore, being better or worse off is caused by individual preference satisfaction. For Hausman and McPherson (2006, pp. 67-68), the Pareto criterion functions "as a Trojan horse smuggling ethical commitments into the theoretical citadel of positive mainstream economics." It assures economists that economic efficiency is value-free, and allows them to "conclude that, ceteris paribus, perfectly competitive equilibria are morally desirable and market imperfections that interfere with the achievement of competitive equilibria are morally undesirable" (p. 66).

The second issue is rational choice theory, which many economists perceive as a positive approach (Thaler, 1980). It would be a descriptive theory if economists make a systematic empirical observation of the agent's preferences and choices and then generalize those observations to derive some scientific laws of economic behavior (Hands, 2012). However, this is not how economic analysis is done in most cases. As mentioned before, economists cannot observe people's beliefs and desires. Therefore, they concentrate on people's choices. However, neoclassical economists do not only say that someone chooses something, but they indicate that someone chose something because it maximizes their utility or satisfies their preferences (revealed preference theory). Neoclassical economists also assume that one's choice is rational. Economists are content to use instrumental 
rationality, which enables them to be value-free because they do not say what choice people should make to maximize their utility. However, some economists forget that they make assumptions about instrumental rationality. They assume that preferences must be transitive and complete to be called rational (satisfying a weak axiom of revealed preferences).

To conclude the discussion on normative-positive economics, the distinction between is and ought is exaggerated. Putnam thinks that the dichotomy should be "disinflated":

If we disinflate the fact/value dichotomy, what we get is this: there is a distinction to be drawn (one that is useful in some contexts) between ethical judgments and other sorts of judgments. This is undoubtedly the case, just as it is undoubtedly the case that there is a distinction to be drawn (and one that is useful in some contexts) between chemical judgments and judgments that do not belong to the field of chemistry. But nothing metaphysical follows from the existence of a fact/value distinction in this (modest) sense. (Putnam, 2002, p. 19)

Moreover, economists should understand that they are not as positive as they like to see themselves. Economic theories (Rational choice theory, the Pareto optimum) contain normative components, but to understand that, economists need to extricate themselves from positivistic influence. No social science can be entirely value-free, and in the end, economists deal with human goals (see Hausman \& McPherson, 2006; Fiedor \& Ostapiuk, 2017; Reiss, 2017; Ostapiuk, 2019b, 2020; Hardt, 2020). To do that properly, economists need to have a debate on goals and normative approaches.

\subsection{Popper, Friedman, and economics}

In the discussion on economic methodology, we cannot forget about Friedman (1953). For him, the main thing that matters is the prediction of a novel fact. It means that evidence that had never been observed determines if an economic theory is successful. Friedman writes that the "ultimate goal of a positive science is the development of a 'theory' or 'hypothesis' that yields valid and meaningful ... predictions about phenomena not yet observed" (1953, p. 7). Most economists see Friedman as an instrumentalist because they think that he does not care about the realism of the assumptions (Boland, 1979; Caldwell, 1992). ${ }^{1}$ They are only used to predict novel facts. According to Friedman, "the relevant question to ask about the 'assumptions' of a theory is not whether they are descriptively 'realistic,' for they never are, but whether they are sufficiently good approximations for the purpose in hand" (Friedman, 1953, p. 15) and "in general, the more significant the theory, the more unrealistic the assumptions" (p. 14).

\footnotetext{
${ }^{1}$ However, Mäki (2009) argues that Friedman's position is more complicated and cannot be identified as mere instrumentalism. Due to many ambiguities and inconsistencies in F53, Friedman's position is open to various interpretation (as realist statement or/and as socially constructivist fallibilism). Hoyningen-Huene (2017) also argues that Friedman should not be interpreted as instrumentalist. To show that he investigates the concept of 'ideal type' in F53.
} 
Popper's falsificationism was pretested in the first section. Here it is analyzed from the perspective of economics. There are two main problems with falsificationism. Firstly, economists have never really practiced it. Blaug wrote, "Modern economists frequently preach falsificationism... but they rarely practice it: their working philosophy of science is aptly described as "innocuous falsificationism"" (1992, p. 111). Of course, economists engage in empirical research, which should make their theories more prone to falsification, but

much of it is like playing tennis with the net down: instead of attempting to refute testable predictions, modern economists all too frequently are satisfied to demonstrate that the real world conforms to their predictions, thus replacing falsificationism, which is difficult, with verification, which is easy. (Blaug, 1992, p. 241)

Economists do not falsify their theories; rather, they verify them, which shows the lasting influence of logical positivism on economics.

Problems with falsificationism are deeper. Many economists do not fully understand underdetermination and theory-ladenness. They see falsificationism as a special type of empiricist foundationalism (logical positivism) but without the problem of induction (Hands 2001, p. 292). Popper was never an empirical foundationalist. Therefore, economists are Popperians for the wrong reasons (p. 292). Secondly, if they had read Popper in a modern way, they would not be Popperians because falsificationism does not provide a methodology that shows how science must be done, making a solid demarcation line between sciences and pseudosciences. In the end, it is impossible to escape from metaphysics.

\section{Value-free economics vs. the real world}

The perception of economics as value-free science causes problems not only in theory but also in real life. Many economists treat instrumental rationality, The Pareto optimum, and effectiveness as positive, not normative conceptions. This perception has led to the belief that well-being in economics is a positive theory. This is wrong because there is no descriptive theory of well-being. It is impossible to discuss well-being without making some value judgments. Many economists did not see that because they used a formal, not a substantive theory of well-being that does not say what good ultimately is but tells us how to find what is good for people (Hausman \& McPherson, 2006, p. 119). We should just wait and see what people choose. Because of that, "economists should not have substantive views about the conception of the good. But this is of course to make a moral judgment and to subscribe to a particular theory of well-being: namely, wellbeing is what people desire" (Reiss, 2013, p. 214).

The conception of well-being based on revealed preferences is very problematic. Behavioral economics and economics of happiness show that people do not have stable preferences. Frequently they are created "on the fly." Preferences are 
context-dependent (Sen, 1993; Kahneman \& Tversky, 1979), change with time (Ainslie, 1975), and are malleable (Brickman, Coates \& Janoff-Bulman, 1978). Moreover, people have cognitive biases that are not anomalies but an inherent feature of human beings (Thaler, 2015). Due to these problems, revealed preferences are not always a good indicator of well-being.

If we know about the problems of value-free economics, how is it possible to use rational choice theory or revealed preferences? Nowadays, many economists argue that neoclassical economics has always known that people are not fully rational, and homo economicus was a necessary simplification of the world, not a description. However, it is not the complete truth. Many economists created models based on assumptions of full rationality, and they were used in real life. It was the case in the times of neoliberalism, when people were presented as rational agents who know what is best for them (Thaler, 2015; Rodrik, 2015). The goal of this article is not to blame economists. The goal is to underline that models perform reality, and sometimes scientists can confuse their models with reality (Callon, 2006; Morgan, 2012; Boldyrev \& Svetlova, 2016). Homo economicus used by neoclassical economists is a paradigm, the lenses by which they look at reality. Economists tailor reality to their theories. This was indicated by Callon (2006) in the concept of performativity. Economic theories also influence the people who become familiar with them. Hausman and McPherson wrote, "it seems that learning economics may make people more selfish" (2006, p. 305). Many economists believe that people are rational and egoistic. Therefore, when behavioral economics, which questions these assumptions, started to develop, it attracted criticism from neoclassical economists (Thaler, 2015).

Of course, homo economicus and rational choice theory have been criticized for a very long time, but since the 1980s, the criticism has increased. Psychologists, sociologists, and philosophers have criticized neoclassical economics' views on people and rationality. Still, not only did economics not change their view, but it was able to thrive ('economic imperialism' Lazear 2000, see Brzeziński, Gorynia \& Hockuba, 2008). How was it possible that this criticism did not affect economics? It was possible thanks to economists' specific perception of rationality and utility. Becker (1976), with his economic approach, is the best example of where value-free economics leads. He perceives rationality instrumentally. It means that we care about the means, not the ends that individuals put on themselves. Therefore, we can perceive all behaviors as rational. From this perspective, it does not matter whether someone is a homeless drug addict without work and family or a happy and successful person with a happy family life. In both cases, the person is rational. The same method is used in the case of utility, which is perceived ad libitum. It means that Becker put altruism, empathy, and a sense of fairness in the bottomless pit of maximization. Hence, self-interest (the maximization of utility) can manifest itself both as a donation of a kidney to a stranger and the murderer of this person. This perception of utility and rationality means that in the economic approach, every behavior meets the requirements (created by Becker) of rationality and the maximization of utility. Therefore, the economic approach is based on axiomatic assumptions that are nothing more than 
tautologies, which causes the model to always work. Hence, criticizing economic assumptions as unrealistic does not have any effect. The economic approach works. This is why so many economists still believe in value-free economics and champion the mathematical approach (see Ostapiuk, 2019a, 2020).

After World War II, economists started to look like the scientific community in The Glass Bead Game (Hesse), where scientists live in an ivory tower and do not care about reality. Blaug (1997, p. 3) wrote: "economy increasingly become an intellectual game played for its own sake and not for its practical consequence for understanding the economic world." Many economists create theories for theory's sake. It does not matter whether they are true or accurate. The only important thing is if theories are closed axiomatic systems that logically work. Of course, many things have changed in economics since the peak of mathematization in the 1970 and 1980s. Since then, we have experienced the rise of behavioral economics and new institutional economics, which focus on how people really behave, and which rely more on data than an axiomatic theory. However, as was underlined before, many authors argue that the soul of economics has not changed, and it is still based on the formalistic method and closed axiomatic system (Berg \& Gigerenzer, 2010; Dow, 2012; Lawson, 2015; Madra, 2016; Ostapiuk, 2020).

The ongoing fascination with the effectiveness of theories, not their accuracy toward reality, displays economics' schizophrenia. On the one hand, economists are naïve realists who believe in objective (measurable) data and logical positivism. On the other hand, they use instrumentalism, where truth cannot be known, and prediction is what matters because of its usefulness. This inconsistency is the result of economists' opportunism and lack of methodological knowledge. They use methodologies that suit them. Objective data give economists a firm, scientific foundation that distinguishes them from other social scientists. Instrumentalism with disbelief in the truth gives economists justification for simplified mathematical models that do not explain reality. They only need to have predictive power.

The arguments against objectivity have been presented before, so let us indicate some problems with instrumentalism. Philosophers of science often use the example of Ptolemy's astronomy, which assumes that the earth is at the center of the universe. Although this theory is false, it has strong predictive power, and it is useful. It guides navigation, and it helps create a more accurate calendar. If we had judged only its usefulness, we would hold to this theory. However, nobody treats Ptolemy's astronomy seriously. In general, instrumentalism is not wrong in stating that there is no truth, which is why science's ultimate goal is usefulness. Instrumentalism has its roots in pragmatism but goes too far. Pragmatists like James or Peirce did not argue that theories cannot be true or false. They just argued that theories must serve practical ends (cash value), although the cash value of a theory is not only its predictive power. If theories are like instruments that we use, then we need to know for what purpose we need them. A barometer measures air pressure. Thanks to that, people can predict and anticipate weather changes. However, other tools are necessary to control the weather. A barometer alone can only assist in measurement or observation (Hausman, 1998, p. 190). Conversely, the hammer helps one to act. Both of these instruments have different purposes. 
Therefore, the idea of theories as tools is ambiguous. "Should it aim to give them tools to measure and passively to predict, or should it aim to give them tools to act and to control?" (p. 190).

We should step down from these abstractions toward real economic problems. For a while, Phillip's curve enabled economists to predict the rate of unemployment connected with inflation rates. However, the relationship ended when governments started to use this relation to regulate the rate of unemployment. Why did it happen? Prediction requires only knowledge of stable correlations, whereas control demands knowledge of causation (Hausman, 1998, p. 190). Instrumentalists do not care about this distinction because they believe that the only practical goal is prediction. After all, we cannot know the truth. Consequently, many of them do not notice that the knowledge of causes has a practical end (control). Therefore, Hausman (1998) argues that the search for causes is central to science. In general, most philosophers of science are not instrumentalists. They agree that the goal of science is both predictive and explanatory (Hausman, 1992; Hands, 2001; Reiss, 2013).

The above-mentioned criticism has a bearing on value-free economics. Firstly, prediction is not the only thing that matters; explanation is also important. Therefore, economists should not create theories whose only purpose is to work logically. Economics cannot be only an intellectual game. Secondly, there is no unbridgeable distinction between normative and positive approaches. Moreover, the economic theory of well-being contains normative statements. From this perspective, it is justified to argue that economics should be closer to reality and help people achieve a good life. To do that, economists need to consider normative approaches worth studying. Many economists still believe in the ought-is distinction, and they consider a discussion on values meaningless. As a scientific community, we need to understand and accept that we may never find conclusive answers about individuals' ends. However, it does not mean that we cannot and should not discuss them. Therefore, the last part of the article concerns the discussion on values.

\section{Put your values on the table}

It had been presented before where value-freeness has led economists. Paradoxically, Weber's works show why economists need to deal with values. It may sound like a paradox because many economists regard Weber as the founder of value-free economics. This misinterpretation of Weber has been possible because his ideas are complex, which can lead to ambiguity. There is much discussion whether by value-freeness he means ethical neutrality of researcher, or that we should deal with facts without an axiomatic ingredient, or that we cannot express normative statements at all (Klimczak, 2014).

In the beginning, it is essential to underline that Weber did not try to present a systematic epistemological treatise that would end the "strife over methods" 
(Methodenstreit) between positivism and historicism. His goal was much more pragmatic. Wolin wrote that Weber "formulated the idea of methodology to serve, not simply as a guide to investigation but as a moral practice and a mode of political action" (1981, p. 414). For Weber, ethics and science are interlinked. He demands intellectual honesty from scientists who make claims about scientific truths and hypotheses (van Dun, 1986, p. 19). Weber knows that scientists cannot escape from values. Therefore, they should scrutinize them honestly. From this perspective, "it would perhaps be better to drop the term Wertfreiheit altogether, and to speak only of "freedom from prejudice"” (p. 20). The only place where Weber is explicitly against values in science is when he argued against lecturers who impose ideologies on students (Weber, 1949, p. 5).

In Weber's opinion, we cannot escape from values in scientific work. Even our interest in some fields is triggered by some values that we cherish. Weber was pragmatic, and he understood that if we cannot eliminate our values, then we should scrutinize them rationally. Weber makes a distinction between "instrumental value judgments" and "methodological value judgments." Instrumental value judgments should make discussion possible and fruitful. They can take the form of (1) assessing the internal consistency of the value premises from which various normative judgments are derived, (2) deducing the implications of these value premises in the context of the specific circumstances to which they are used, and (3) observing the factual consequences of different ways of achieving normative judgments (1949, pp. 20-21). Methodological value judgments cannot be checked, but without them, science could not exist. They are the main assumptions of scientific approaches. In value-free economics, we can indicate methodological value judgments like the invisible hand, equilibrium, instrumental rationality, and revealed preferences. Even though we cannot find an objective basis to compare these values, we need to investigate them. Scientists must practice a "contemplative attitude" toward these values (Schweitzer, 1970, p. 83). Contemplation does not mean indifference toward values but impartiality. Scientists have to accept the subjectivity of science, and this is why they should be self-consciously subjective. What kind of implication does it have on value-free economics? Firstly, it is impossible to eradicate values from economics because of methodological value judgments. Secondly, economists can use Weber's insight to see the normativity of their fundamental assumptions, which many treat as positive ones.

Nagel and Sen, like Weber, wanted to prove that science can work despite its value-ladenness. Nagel (1961) distinguishes "characterizing value judgments" and "appraising value judgments." Characterizing value judgments contains criteria that can be assessed (by logic or data). Different judgments can be compared thanks to objective criteria. On the other hand, "appraising value judgments" evaluate states of the world. For example, the desirability of a particular kind of human behavior, or an assessment of the outcomes created by that behavior. Scientists cannot choose between appraising value judgments because there are no objective criteria to do so. There is only social power. Nagel understands that science cannot work without values. However, he believes that science can be free, at least, from "appraising value judgments," and it can stick to "characteriz- 
ing value judgments" that can be compared by the scientific method (pp. 492-495). Sen made a similar distinction. He differentiates "basic" and "nonbasic" value judgments. Sen explains that "a value judgment can be called 'basic' to a person if the judgment is supposed to apply under all conceivable circumstances, and it is 'nonbasic' otherwise" (1970, p. 59). This distinction is essential because it draws the line between science and non-science. If we have basic value judgments that state that freedom is the most important value and we do not consider any other value (e.g., happiness), then it is impossible to have a discussion because discussion assumes that we can change our opinion due to the arguments that are presented. So long as a value judgment is "nonbasic," we can have a discussion because we can convince the other side by appealing to some facts/arguments. The essence of science is a discussion within which the participants can change their opinions. If we do not have a discussion, we do not have science. Therefore, only "nonbasic" judgments make science possible.

Blaug observes that the methods that give scientists the ability to discuss values are not ironclad. He wrote: "the difference between the methods of reaching agreement on methodological judgments and value judgments is one of degree, not of kind" (1992, p. 116). Blaug noticed that there is a difference between an is and ought statement, but "at the deep philosophical level, this distinction is perhaps misleading" (pp. 114-115). He underlines that so-called facts must also rely on the acceptance of some rule of the scientific game which strives for objectivity. However, it will never be achieved entirely because accepting scientific rules depends on the scientific community, and it is done by persuasion. A similar point was made by McCloskey (1983), which is investigated in the last section.

Although Blaug agrees that science is theory-laden, he thinks that Nagel's distinction between characterizing (methodological) and appraising (normative) judgments is real and significant (1992, pp. 114-115). Without this difference, we will fall into absolute relativism, which does not offer a lot. Some difference between is/ought is necessary, which is visible in the case of Myrdal (1970), who argues that every statement is equally value-laden. Of course, an inflation rate is theory-laden. We normatively decide which products and services should be inclined in this measurement. However, when the rate of inflation is presented, it is the same rate for everyone, and this kind of objectivity is essential for science.

The purpose of this section was to indicate that scientists cannot escape from values. They deal with values even though they cannot decide which of them is true. From this perspective, it seems uncontroversial that economists can work on normative approaches which were dismissed in logical positivism. Of course, at the core, they concern normative statements. However, thanks to "instrumental value judgments," we can check if they are logically consistent and if the evidence supports them. In the case of "methodological value judgments," which cannot be eradicated from science, it is better to put these values on the table and make them transparent than hide them in a disguise, as is done by positive economics. The distinction between is and ought is not unbridgeable, and there is no escape from relativity. However, scientists should not be afraid of relativism because some mechanisms make the scientific endeavor a successful enterprise. 


\section{Dancing on the cliff of relativism}

The old methodology designed to find truth is dead. However, it does not mean the end of philosophy (Hands, 2001). The lack of a strict methodological corset is not a catastrophe, and it can even be liberating for scientists. Why should we be so optimistic? Firstly, one can find similarities between contemporary relativistic science and ethics at the end of the $19^{\text {th }}$ century. Understanding that 'God is Dead' moved many intellectuals, who thought that without a higher set of rules given by God, society would fall into anarchy. Dostoyevsky best vocalized this attitude when he stated that "Without God, all things are permitted." As we can observe now, nothing of the kind happened (Pinker, 2011). We discovered that we do not need to have absolute rules to lead a good and moral life. It is possible to drive a parallel here and argue that science can thrive without absolute rules.

One hundred years ago, ethics (for the most part) dropped the claim that we can discover whether some actions are fundamentally right or wrong in a moral sense. For scientists, it takes much more time to accept relativity because of the specificity of science. People become scientists because they want to know the truth. Therefore, it is extremely difficult to let the idea of truth go. This is especially the case for hard science, which deals with data, facts, and universal rules. It also concerns economics, which aspires to be hard science. From the perspective of the contemporary philosophy of science, scientists should be more like artists and accept relativity. Kuhn also makes this point: "Like artists, creative scientists must occasionally be able to live in a world out of joint" (1996, p. 79). As scientists, we cannot obligingly follow some methodology. We must be ready to change our paradigms all the time. From this perspective, the death of logical positivism and fundamentalist methodology (Received view) is a positive change. Thanks to that, metaphysics and ontology can be seriously discussed in economic methodology. Moreover, changes in the philosophy of science lead to a revival of pragmatism. This philosophical system provides a third way between two main approaches in metascience: foundationalist philosophy and radical relativism. Pragmatism is an alternative because it is antifoundationalist, but it also treats science as something special.

The death of fundamentalist philosophy means the dismissal of scientific monism, which has been cherished by neoclassical economics for years. Nowadays, methodological pluralism seems to be the only game in town. It must be underlined that pluralism does not mean that anything goes, and everything is equally subjective as in relativism (Dow, 2012). It means that there are different methodologies and approaches suitable for different situations. Therefore, there is no single approach that works for every situation. It teaches humility and tolerance for other ideas.

Secondly, we should not be afraid of relativism because of the way the scientific community works. Lakatos (1980) presented a quasi-historical approach to choosing which methodology is better. He argues that the scientific elite itself decides which methodology is superior. Does it sound reasonable to ask where 
this belief in the scientific community came from? Merton was a sociologist who proposed four values that characterize the ethos of sciences and make them successful (CUDOS-norms):

(1) communism: all scientists should have common ownership of scientific goods (intellectual property) to promote collective collaboration; secrecy is the opposite of this norm;

(2) universalism: scientific validity is independent of the socio-political status and personal attributes of its participants;

(3) disinterestedness: scientific institutions act for the benefit of a common scientific enterprise rather than for the personal gain of individuals;

(4) organized skepticism: scientific claims should be exposed to critical scrutiny before being accepted. (Merton, 1942, pp. 118-126)

Of course, it is possible to indicate many instances where these rules are violated. However, if we look at the history of science, we can see that most scientists respect these rules. Although the decision of the scientific community is relative, the practice of doing science is a reliable standard (the best we have).

Scientists and their practice make science a successful endeavor even though we do not have rules to find the truth. The lack of rules is not a problem for scientists. Conversely, Poincaré (2010) gives a psychological explanation of scientific work where scientists' creativity, not sticking to rules, makes their work successful. At the beginning, scientists gather data and read books to resolve some problems. However, often the problem cannot be solved. When relying on knowledge does not work, the subconscious work begins (e.g., during sleep). A scientist has a flash of insight, and she finds a solution that is consciously checked later. Poincare compares scientists to musicians who look for beauty and harmony. A scientist, like a musician, can find beautiful motifs in random voices. Later, scientists cannot explain how they find a solution because often, the process takes place in subconsciousness. A similar argument about scientific creativity was made by Michael Polanyi (1958). He is well known for the concept of "tacit knowledge." The best example is riding a bike. We cannot explain to someone how to do it, we just do it (learning by experience). In the context of science, tacit knowledge means that scientists look at the best articles and arguments of other scientists, thanks to which, they learn what a good article looks like. They do not know this because some strict rules define which article is good but because they "experience" good articles.

The normativity of the scientific community attracts much criticism. It is especially visible in the case of McCloskey's rhetorical approach. In general, she argues that fundamentalist methodology does not work. Scientific theories are theory-laden and underdetermined; science is contextual and interest-laden. Also, psychological dichotomies, like positive versus normative, theory versus observation, a priori versus a posteriori, are inadequate. Because it is impossible to find epistemic truth, McCloskey argues that scientists are like other people and they are convinced by persuasion (Klamer, McCloskey \& Solow, 1988). She wrote: "If we decide that the quantity theory of money or the marginal productivity theory of 
distribution is persuasive, interesting, useful, reasonable, appealing, acceptable, we do not also need to know that it is True" (McCloskey, 1994, pp. 46-47). Because of this view, she is branded an irrationalist by many economists. Her rhetorical approach dismisses Truth and Methodology. Many economists think that this position leaves us with "anything goes." McCloskey does not:

\begin{abstract}
Of course, some arguments are better than others. Anything does not go. Recognizing that nonetheless they are all arguments does not entail slipping into a hot tub of "relativism" as defined by conservative philosophers of science. One does not give up the ability to distinguish between the Ajax Kitchen Cleanser jingle and Gödel's Proof by noting that both are designed with an audience in mind, with a perlocutionary force, with patterns of repetition, ... and all the rest. (McCloskey, 1994, p. 290)
\end{abstract}

Despite relativity, McCloskey thinks that we can compare different arguments and decide which is better. Mäki (1995) uses this insight and argues for rhetorical realism, where persuasion alone is not enough in scientific debate. Some truths are independent of the persuasive efforts and the beliefs of debaters (Mäki, 2012). These truths refer to some universal audience or rules, not to the tyranny of the majority. For McCloskey and Mäki, rhetoric is something different than sophism, where the goal is to persuade people of some idea at all costs. In scientific discourse, we also try to convince other scientists, but we do this by adhering to some rules like logic or correspondence to data. Of course, these rules are created and objectified by scientists, and this makes them normative. However, this is the best science can do, and it works. Moreover, there is a difference between sophism, where the only goal is winning a debate, and scientific rhetoric, where one plays by the rules, independent of one's self-interest. Scientists want to win fairly by using rules, as in a chess game. They do not wait for an opponent to go to the toilet and then change the positions of the pawns.

The fierce criticism of McCloskey means that many economists do not fully understand the changes in the philosophy of science. Nowadays, the goal of science is not to find the truth but to function in the relative world. It should not be so frightening when we observe that we can rationally discuss some values (it is not a shouting contest). We cannot escape from relativism or values. Therefore, we should be self-conscious about the rules that we use.

This relative idea of truth was presented more than one hundred years ago by Nietzsche, who also perceived truth as provisional and relative to the knower. For him, truth is "a mobile army of metaphors, metonyms, and anthropomorphisms" (Nietzsche, 1954, p. 46). However, Nietzsche never argued against improving our knowledge. He prescribed active, not passive nihilism. Megill (1985, p. 34) wrote:

Nietzsche prescribes this nihilism as the appropriate attitude for modern, and postmodern, existence. Instead of drawing back from the void, we dance upon it. Instead of lamenting the absence of a world suited to our being, we invent one. We become the artists of our own existence, untrammeled by natural constraints and limitations. 
We should accept the fact that there is no absolute truth and objectivity. Accepting reality is better than denial. Unfortunately, by sticking to an obsolete positivistic view of science, this is what many economists do.

In the end, the slippery slope of relativity ends somewhere, and it ends for a reason. If we want to argue that we ought not to be reasonable, we need to give reasons for this position. We cannot reasonably deny that we ought to be reasonable. So, the question of whether or not we ought to be reasonable must lead to the conclusion that we ought. We know this from Aristotle. In Protrepticus (Barnes, 1984, pp. 3, 17-23), he argued that the question of whether we ought to philosophize or not logically permits only one answer. We ought to philosophize.

Aristotle is used here to reassure economists who are afraid of "anything goes" and the relativity of science. Accepting relativity does not necessarily lead to anarchism and the end of science. Therefore, economists do not have to stick to logical positivism and methodological monism. Moreover, it is possible to be open towards methodological pluralism and normative approaches, which are treated as unscientific because they concern subjective goals. It is possible because normative approaches can be analyzed and assessed.

\section{Conclusions}

Accepting that science is relative and normative can draw economists a little closer to artists, who are not so corseted by ultimate rules and truth. For them, there are no objective standards of beauty or the ultimate method to define art. They also do not feel a need to find an objective method to choose which piece of art is better. From the perspective of the contemporary philosophy of science, objective truth and ironclad scientific methods do not exist. Nor will economists find an objective method to choose between theories and paradigms. In this light, economists as artists rely on community and institutional standards created by this community, which are normative. Of course, economists use different rules than artists (e.g., facts, arguments, and logic), but the difference is in the degree and not the kind. Neither artists nor economists can have an objective method of how to do their work.

In the end, we can refer once more to Kuhn (1996), who famously underlined the relativity of science. Even though he argued that there are no ultimate methodological rules for science, he was not an irrationalist. He proposed criteria to choose between paradigms (accuracy, consistency, scope, simplicity, and fruitfulness, see Kuhn, 1977). However, these rules are still subjective. Kuhn perceives them as epistemological values that influence science, not determine it. Many scientists are not impressed by these vague guidelines because they want scientific rules that define truth, delineate objective facts, and distinguish between science and pseudo-science. However, we will not find such rules. At the end of the day, economists as artists rely on the community and the institutional rules of the game. This is the best that we can hope for; and these normative rules make discussion possible. 


\section{References}

Ainslie, G. (1975). Specious reward: A behavioral theory of impulsiveness and impulse control. Psychological Bulletin, 82(4), 463-496. https://psycnet. apa.org/doi/10.1037/h0076860

Akerlof, G. (2020). Sins of Omission and the Practice of Economics. Journal of Economic Literature, 58(2), 405-418.

Angner, E. (2019). We're all behavioral economists now. Journal of Economic Methodology, 26(3), 195-207.

Backhouse, R. E. \& Cherrier, B. (2017). The age of the applied economist: the transformation of economics since the 1970s. History of Political Econo$m y, 49,1-33$.

Barnes, J. (Ed.). (1984). The complete works of Aristotle Vol. 2. Princeton: Princeton University Press.

Becker, G. S. (1976). The economic approach to human behavior. Chicago: University of Chicago Press.

Berg, N. \& Gigerenzer, G. (2010). As-if behavioral economics: Neoclassical economics in disguise? History of Economic Ideas, 18(1), 133-165.

Blaug, M. (1992). The Methodology of Economics: Or How Economists Explain (2nd ed). Cambridge: Cambridge University Press.

Blaug, M. (1997). Ugly Currents in Modern Economics. Options Politiques, $18(17), 3-8$.

Boland, L. A. (1979). A critique of Friedman's critics. Journal of Economic Literature, 17(2), 503-522.

Boldyrev, I. \& Svetlova, E. (Eds.) (2016). Enacting Dismal Science: New Perspectives on the Performativity of Economics. New York: Palgrave Macmillan.

Brickman, P., Coates, D. \& Janoff-Bulman, R. (1978). Lottery winner and accident victims: is happiness relative? Journal of Personality and Social Psychology, 36(8), 917-927. http://dx.doi.org/10.1037/0022-3514.36.8.917

Brzeziński, M., Gorynia, M. \& Hockuba, Z. (2008). Ekonomia a inne nauki społeczne na początku XXI w. Między imperializmem a kooperacją. Ekonomista, 2, 201-232.

Caldwell, B. J. (1992). A Critique of Friedman's Methodological Instrumentalism: A Modification. Research in the History of Economic Thought and Methodology, 10, 119-128.

Callon, M. (2006). What does it mean to say that economics is performative? CSI Working Papers Series, no. 005, Centre de Sociologie de l'Innovation (CSI), Mines ParisTech. 
Cedrini, M. \& Fontana, M. (2018). Just another niche in the wall? How specialization is changing the face of mainstream economics. Cambridge Journal of Economics, 42(2), 427-451. https://doi.org/10.1093/cje/bex003

Colander, D. (2000). The death of neoclassical economics. Journal of the History of Economic Thought, 22(2), 127-143. https://doi.org/10.1080/104277100 50025330

Colander, D., Holt, R. \& Rosser, J. (2004). The Changing Face of Mainstream Economics. Review of Political Economy, 16(4), 485-499. https://doi.org/ 10.1080/0953825042000256702

Davis, J. B. (2006). The Turn in Economics: Neoclassical Dominance to Mainstream Pluralism. Journal of Institutional Economics, 2(1), 1-20. https:// doi.org/10.1017/S1744137405000263

Dow, S. C. (2012). Foundations for new economic thinking: A collection of essays. London: Palgrave Macmillan.

Dun, F. Van (1986). Economics and the Limits of Value-Free Science. Reason Papers, 11, 17-32.

Feyerabend, P. (1993). Against method ( $3^{\text {rd }}$ ed). New York-London: Verso.

Fiedor, B. \& Ostapiuk, A. (2017). Utylitaryzm versus aksjologiczne i społeczne uwarunkowania wyborów ekonomicznych. In: E. Mączyńska \& J. Sójka (Eds.), Etyka i ekonomia. W stronę nowego paradygmatu (pp. 19-44). Warszawa: Polskie Towarzystwo Ekonomiczne.

Fourcade, M., Ollion, E. \& Algan, Y. (2015). The superiority of economists. Journal of Economic Perspectives, 29(1), 89-114.

Friedman, M. (1953). Essays in Positive Economics. Chicago: University of Chicago Press.

Graupe, S. (2019). "Waging the war of ideas": Economics as a textbook science and its possible influence on human minds. In: S. Decker, W. Elsner \& S. Flechtner (Eds.), Advancing pluralism in teaching economics (pp. 173-191). London: Routledge.

Hands, D. W. (2001). Reflection Without Rules: Economic Methodology and Contemporary Science Theory. Cambridge: Cambridge University Press.

Hands, D. W. (2007). Effective tension in Robbins's economic methodology. In: F. Cowell and A. Witztum (Eds.), Lionel Robbins' essay on the nature and significance of economic science. 75th anniversary conference proceedings (pp. 152-168). London: London School of Economics and Political Science.

Hands, D. W. (2012). The positive-normative dichotomy and economics. In: U. Mäki (Ed.), Philosophy of economics (pp. 219-239). Amsterdam: Elsevier.

Hardt, Ł. (2020). Utylitaryzm, deontologia i etyka cnót: zbieżne czy przeciwstawne fundamenty etyczne ekonomii? Ekonomista, 2, 249-265.

Hausman, D. M. (1992). The Inexact and Separate Science of Economics. Cambridge: Cambridge University Press. 
Hausman, D. M. (1998). Problems with realism in economics. Economics \& Philosophy, 14(2), 185-213. https://doi.org/10.1017/S0266267100003837

Hausman, D. M. \& McPherson, M. S. (2006). Economic Analysis, Moral Philosophy and Public Policy. Cambridge: Cambridge University Press.

Hempel, C. G. (1945). Studies in the Logic of Confirmation (I.). Mind, 54(213), $1-26$.

Hoyningen-Huene, P. (2017). Revisiting Friedman's F53. Popper, Knight, and Weber. http://philsci-archive.pitt.edu/12910/1/Friedmans\%20F53.pdf

Hutchison, T. W. (1981). The Politics and Philosophy of Economics. New York: New York University Press.

Kahneman, D. \& Tversky, A. (1979). Prospect Theory: An Analysis of Decision under Risk. Econometrica, 47(2), 263-292. https://doi.org/10.2307/1914185

Keynes, J. N. (1999). The scope and method of political economy. Kitchener, Ontario: Batoche Books.

Klamer, A., McCloskey, D. N. \& Solow, R. M. (Eds.). (1988). The consequences of economic rhetoric. Cambridge: Cambridge University Press.

Klappholz, K. (1964). Value Judgments and Economics. British Journal for the Philosophy of Science, 15(58), 97-114.

Klimczak, B. (2014). Aksjologiczne uwikłanie ekonomii. Annales. Etyka w Życiu Gospodarczym, 17(1), 9-21.

Kuhn, T. S. (1977). Objectivity, Value Judgment, and Theory Choice. In: T. S. Kuhn, The Essential Tension: Selected Studies in Scientific Tradition and Change (pp. 320-339). Chicago: University of Chicago Press.

Kuhn, T. S. (1996). The Structure of Scientific Revolutions (3 ${ }^{\text {rd }}$ ed). Chicago: University of Chicago Press.

Lakatos, I. (1980). The methodology of scientific research programmes. Philosophical Papers, Volume 1. Cambridge: Cambridge University Press.

Lawson, T. (2015). Essays on: The Nature and State of Modern Economics. Abingdon: Routledge.

Lazear, E. P. (2000). Economic imperialism. Quarterly Journal of Economics, 115(1), 99-146. https://doi.org/10.1162/003355300554683

Madra, Y. M. (2016). Late Neoclassical Economics: The restoration of theoretical humanism in contemporary economic theory. New York: Routledge.

Mäki, U. (1995). Diagnosing McCloskey. Journal of Economic Literature, 33(3), $1300-1318$.

Mäki, U. (2009). Unrealistic assumptions and unnecessary confusions: Rereading and rewriting F53 as a realist statement. In: U. Mäki (Ed.), The methodology of positive economics. Reflections on the Milton Friedman legacy (pp. 90-116). Cambridge: Cambridge University Press. 
Mäki, U. (2012). Realism and antirealism about economics. In: U. Mäki (Ed.), Philosophy of economics (pp. 3-24). Amsterdam: Elsevier.

McCloskey, D. N. (1983). The rhetoric of economics. Journal of Economic Literature, 21(2), 481-517.

McCloskey, D. N. (1994). Knowledge and Persuasion in Economics. Cambridge: Cambridge University Press.

Megill, A. (1985). Prophets of Extremity: Nietzsche, Heidegger, Foucault, Derri$d a$. Berkeley: University of California Press.

Merton, R. K. (1942). A note on science and democracy. Journal of Legal and Political Sociology, 1, 115-126.

Miller, D. (1974). Popper's Qualitative Theory of Verisimilitude. The British Journal for the Philosophy of Science, 25(2), 166-177.

Mirowski, P. (2002). Machine dreams: Economics becomes a cyborg science. Cambridge: Cambridge University Press.

Mongin, P. (2001). Value Judgments and Value Neutrality in Economics: A Perspective from Today. https://citeseerx.ist.psu.edu/viewdoc/download?doi= 10.1.1.200.2887\&rep=rep1\&type $=$ pdf

Morgan, M. (2012). The world in the model: How economists work and think. Cambridge-New York: Cambridge University Press.

Myrdal, G. (1970). Objectivity in Social Research. London: Gerald Duckworth.

Nagel, E. (1961). The Structure of Science. Problems in the Logic of Scientific Explanation. London: Routledge \& Kegan Paul.

Nietzsche, F. (1954). On Truth and Lie in an Extra-Moral Sense. In: W. Kaufmann (Ed. \& Transl.), The Portable Nietzsche. New York: Penguin Books.

Ostapiuk, A. (2017). Matematyzacja ekonomii - grzech pierworodny? Wieloaspektowa analiza wpływu i przyczyn. Ekonomia XXI wieku, 13(1), 91-104.

Ostapiuk, A. (2019a). Droga ekonomii wolnej od wartościowania do epistemologicznej pychy. Użycie i nadużycie matematyki przez ekonomistów. Zagadnienia Filozoficzne $w$ Nauce, 67, 153-202.

Ostapiuk, A. (2019b). Human Now versus Human over Time. When Instrumental Rationality and Utility Are Not Enough. Panoeconomicus, 66(5), 633-657.

Ostapiuk, A. (2020). The Eclipse of Value-Free Economics. The concept of multiple self versus homo economicus. Wrocław: Wydawnictwo Uniwersytetu Ekonomicznego we Wrocławiu.

Pinker, S. (2011). The better angels of our nature: The decline of violence in history and its causes. New York: Penguin Group.

Poincaré, H. (2010). Science and method (F. Maitland, transl.). New York: Cosimo Classics.

Polanyi, M. (1958). Personal knowledge: Towards a post-critical philosophy. London: Routledge \& Kegan Paul. 
Popper, K. (1959). The logic of scientific discovery. New York: Basic Books.

Putnam, H. (2002). The Collapse of the Fact/Value Dichotomy and Other Essays. Cambridge: Harvard University Press.

Quine, W. V. (1951). Main trends in recent philosophy: Two dogmas of empiricism. The Philosophical Review, 60(1), 20-43.

Ratajczak, M. (2014). Ekonomia i edukacja ekonomiczna w dobie finansyzacji gospodarki. Ekonomista, 2, 207-219.

Reiss, J. (2013). Philosophy of economics: A contemporary introduction. Abingdon: Routledge.

Reiss, J. (2017). Fact-value entanglement in positive economics. Journal of Economic Methodology, 24(2), 134-149. https://doi.org/10.1080/1350178X. 2017.1309749

Robbins, L. (1932). An essay on the nature \& significance of economic science. London: Macmillan.

Rodrik, D. (2015). Economics rules: The rights and wrongs of the dismal science. New York: W.W. Norton \& Company.

Samuelson, P. (1952). Economic Theory and Mathematics - an Appraisal. American Economic Review, 42(2), 56-66.

Schweitzer, A. (1970). Typological Method in Economics: Max Weber's Contribution. History of Political Economy, 2(1), 66-96.

Sen, A. K. (1970). Collective Choices and Social Welfare. Edinburgh: Oliver \& Boyd.

Sen, A. K. (1987). On Ethics \& Economics. Malden, MA: Blackwell.

Sen, A. K. (1993). Internal Consistency of Choice. Econometrica, 61(3), 495-521.

Thaler, R. H. (1980). Toward a Positive Theory of Consumer Choice. Journal of Economic Behavior and Organization, 1(1), 39-60. https://doi.org/10.10 16/0167-2681(80)90051-7

Thaler, R. H. (2015). Misbehaving: The Making of Behavioral Economics. New York: W.W. Norton \& Company.

Thaler, R. H. (2016). Behavioral economics: Past, present, and future. American Economic Review, 106(7), 1577-1600.

Weber, M. (1949). The methodology of the social sciences (E. Shils \& H. Finch, transl.). Glencoe: The Free Press.

Weintraub, E. R. (2002). How economics became a mathematical science. Durham-London: Duke University Press.

Witztum, A. (2007). Ethics and the science of economics: Robbins's enduring fallacy. In: F. Cowell and A. Witztum (Eds.), Lionel Robbins' essay on the nature and significance of economic science. $75^{\text {th }}$ anniversary conference proceedings (pp. 57-85). London: School of Economics and Political Science.

Wolin, S. S. (1981). Max Weber: Legitimation, Method, and the Politics of Theory. Political Theory, 9(3), 401-424. 